\title{
Systemic Lupus Erythematosus
}

\section{STUDIES OF THE ANTIBODIES BOUND TO SKIN}

\author{
Madeleine LANDry and W. Mrtchell Sams, Jr. \\ From the Mayo Clinic and Mayo Foundation, Rochester, Minnesota 55901
}

\begin{abstract}
A B S T RACT Systemic lupus erythematosus is characterized by antibodies demonstrable by immunofluorescence on the renal glomeruli and at the basement membrane area of both normal and involved skin. Acid eluates from glomeruli and from normal-appearing skin of three patients with systemic lupus erythematosus contained an antinuclear antibody. This antibody fixes complement and produces a mixed immunofluorescent pattern. Anti-deoxyribonucleic acid or antiextractable nuclear antigen antibodies may be present. This antibody is concentrated on the skin and glomerular basement membrane in proportion to the total serum IgG concentration. In two cases the skin eluate contains, in addition to the antinuclear antibody, a basement membrane antibody that fixes complement, gives a linear immunofluorescent pattern, and appears to be similar (although not identical) to the pemphigoid antibody.
\end{abstract}

\section{INTRODUCTION}

One of the characteristics of systemic lupus erythematosus $(\mathrm{SLE})^{1}$ is that antibodies may be bound to the basement membrane of the skin. Antibodies (usually IgG type) may be found in the skin lesions in as many as $90 \%$ of patients with SLE and in clinically normal skin in as many as $60 \%$ of such patients $(1,2)$. Because this antibody appears in a lumpy-bumpy pattern, it probably represents an immune complex, similar to that found on the renal basement membrane, rather than an antibody directed specifically to the skin basement membrane. Serum proteins regularly perfuse into the dermis, and at least one IgG antibody has been demonstrated to pass from the vascular system and cross the skin basement membrane to reach the intracellular spaces of the epi-

Received for publication 1 December 1972 and in revised form 21 March 1973.

${ }^{1}$ Abbreviations used in this paper: ENA, extractable nuclear antigen; FITC, fluorescein isothiocyanate; SLE, systemic lupus erythematosus. dermis (3). Because of their size, antigen-antibody complexes might lodge on the basement membrane of skin, as they do on the glomerulus of the kidney.

The purpose of the present investigation was to study the characteristics and specificity of these antibodies from clinically normal skin of patients with SLE. Simultaneously, the antibodies were compared with antibodies from serum and those eluted from kidneys of the same patient.

\section{METHODS}

\section{Tissue and sera}

The clinical and pathologic data of three patients with SLE from whom tissue was obtained at autopsy are detailed in Table I. A strip of normal skin $4 \mathrm{~cm}$ wide and $25-30 \mathrm{~cm}$ long was taken from the margin of the autopsy incision, and one-half kidney (cases 1 and 2) or one whole kidney (case 3 ) was obtained. All tissues were frozen at $-70^{\circ} \mathrm{C}$ within $12 \mathrm{~h}$ after death. Blood was obtained during the 2 wk preceding death (cases 1 and 2) or at autopsy (case 3). Control skin was taken from a patient without clinical or serologic evidence of SLE who had undergone radical mastectomy for breast carcinoma.

\section{Immunofluorescence}

Direct immunofluorescence. Direct immunofluorescence was performed on all tissues according to the previously described methods (4), using goat antihuman fluorescein conjugates obtained from Hyland Laboratories, Los Angeles, Calif. (Table II) and tested for specificity by immunoelectrophoresis and radial immunodiffusion. The dilutions of conjugate were selected by indirect immunofluorescence so that sensitivity was maximal and background staining was minimal. The slides were viewed with a Leitz Ortholux microscope (E. Leitz Inc., Rockleigh, N. J.) equipped with a BG-12 primary filter and an 0-51 secondary filter.

Indirect immunofluorescence. Initial indirect immunofluorescence studies in which serum or eluates were examined for antibodies were performed on various tissues to determine which had the best staining characteristics. Those included human blood buffy coat, tumor imprints (breast carcinoma), rat and rabbit liver, guinea pig kidney and esophagus, and human skin. Guinea pig esophagus proved to be the best practical tissue, since it provided both basement mem- 
TABLE I

Clinical, Laboratory, and Autopsy Findings in Three Cases of Systemic Lupus Erythematosus

\begin{tabular}{|c|c|c|c|c|}
\hline Case & Sex, age & History & Laboratory & Autopsy \\
\hline 1 & F, $\quad \begin{array}{l}y r \\
15\end{array}$ & $\begin{array}{l}\text { Fever, arthralgia, skin rash, } \\
\text { myopathy ( } 3 \mathrm{mo}) \text {; on } 60 \mathrm{mg} \\
\text { prednisone, developed } \\
\text { pancreatitis, septicemia, } \\
\text { GI hemorrhage, seizure }\end{array}$ & $\begin{array}{l}\text { LE clot test and } \\
\text { ANA, pos. ; total } \\
\mathrm{CH}_{50}, 32 ; \text { proteinuria } \\
(1.3 \mathrm{~g} / \text { day })\end{array}$ & $\begin{array}{l}\text { Acute pancreatitis and } \\
\text { peritonitis; acute } \\
\text { esophageal ulcers; focal } \\
\text { proliferative nephritis; } \\
\text { cerebral edema }\end{array}$ \\
\hline 2 & F, 40 & $\begin{array}{l}\text { Intermittent thrombophlebitis, } \\
\text { pleurisy, skin rash, } \\
\text { arthralgia }(8 \mathrm{yr}) \text {; on } 60 \mathrm{mg} \\
\text { prednisone, developed } \\
\text { pleuritic pain, GI hemorrhage, } \\
\text { hematuria }\end{array}$ & $\begin{array}{l}\text { LE clot test and } \\
\text { ANA, pos. ; } \mathrm{CH}_{50}, 48 ; \\
\text { proteinuria }(0.3 \mathrm{~g} / \text { day })\end{array}$ & $\begin{array}{l}\text { Acute pancreatitis, sub- } \\
\text { phrenic abscess, and } \\
\text { septicemia; acute esophageal } \\
\text { and gastric ulcers; } \\
\text { proliferative nephritis; } \\
\text { multiple pulmonary emboli; } \\
\text { polyserositis }\end{array}$ \\
\hline 3 & F, 13 & $\begin{array}{l}\text { Arthralgia, fever, chorea, } \\
\text { butterfly rash (4 yr); on } 60 \\
\text { mg prednisone, developed } \\
\text { renal failure, hypertension, } \\
\text { GI hemorrhage, seizure, coma }\end{array}$ & $\begin{array}{l}\text { LE clot test and } \\
\text { ANA, pos.; } \mathrm{CH}_{50}, 6 ; \\
\text { proteinuria }(4.7 \mathrm{~g} / \mathrm{day}) ; \\
\text { blood urea, } 230 ; \mathrm{Hb}, 6.6 \mathrm{~g}\end{array}$ & $\begin{array}{l}\text { Septicemia; diffuse } \\
\text { proliferative nephritis; } \\
\text { chronic pneumonitis (diffuse } \\
\text { hyaline membrane); poly- } \\
\text { serositis (pericarditis, } \\
\text { pleuritis, ascites); } \\
\text { multiple cerebral infarcts }\end{array}$ \\
\hline
\end{tabular}

brane and nuclear antigens. Indirect immunofluorescence staining, with the use of a conjugated antisera to $\operatorname{IgG}, \operatorname{IgM}$, and $\beta_{1} \mathrm{C} / \beta_{1} \mathrm{~A}$ (same as used for direct immunofluorescence), was carried out in the standard fashion (5).

Complement fixation. The complement immunofluorescent technique followed exactly that described by Jordon, Sams, and Beutner (6).

\section{Eluate preparations}

The acid elution procedure was performed as detailed by Koffler, Schur, and Kunkel (7), with modifications as described.

Tissue preparation. The cortex of the kidney was separated from the medulla, cut into small pieces, suspended in $200-300 \mathrm{ml}$ of phosphate-buffered saline at $\mathrm{pH} \mathrm{7.2,} \mathrm{and} \mathrm{ho-}$ mogenized in an ice-jacket blender (VirTis Co., Inc., Gardiner, N. Y.) for $3 \mathrm{~min}$ at medium high speed. This mixture was then centrifuged at $2,000 \mathrm{~g}$ for $30 \mathrm{~min}$ in a refrigerated centrifuge (Sorvall superspeed RC-2; Ivan Sorvall, Inc. Newtown, Conn.). The sediment was resuspended in $400 \mathrm{ml}$

TABLE II

Characteristics of Monospecific Goat Antihuman Fluorescein Conjugates

\begin{tabular}{lccl}
\hline & & $\begin{array}{c}\text { Fluorescein/ } \\
\text { protein } \\
\text { (molar ratio) }\end{array}$ & $\begin{array}{c}\text { Dilution } \\
\text { for use }\end{array}$ \\
\hline & $m g / m l$ & & \\
Anti-IgG & 3.2 & 4.1 & $1: 125$ \\
Anti-IgM & 24.0 & 1.8 & $1: 32$ \\
$\beta_{1} \mathrm{C} / \beta_{1} \mathrm{~A}$ & 25.0 & 3.1 & $1: 8$ \\
\hline
\end{tabular}

of phosphate-buffered saline at $\mathrm{pH} 7.2$ and washed until the supernate was clear (8-10 times). Aliquots of every washing were tested for the presence of antinuclear antibodies by indirect immunofluorescence. Only the first two aliquots showed the presence of a weak antinuclear antibody.

Each strip of skin was carefully defatted and stretched tight on a cork board with the epidermis upward; the epidermis with a thin sliver of dermal connective tissue was removed with a Castroviejo keratome (Storz Instrument Co., St. Louis, Mo.) fitted with a $0.3-\mathrm{mm}$ shim. This preparation was then processed by the same method as that use for the kidney, except that it was homogenized for $10 \mathrm{~min}$.

Acid elution. The preparation of glomeruli was treated with 10 vol of $0.02 \mathrm{M}$ citrate buffer at $\mathrm{pH} 3.2$ and stirred for $2 \mathrm{~h}$ at $37^{\circ} \mathrm{C}$. The suspension was centrifuged at $2,000 \mathrm{~g}$ for $30 \mathrm{~min}$, and the supernate was neutralized with $0.1 \mathrm{~N}$ $\mathrm{NaOH}$ and dialyzed for several days against multiple changes of phosphate-buffered saline at $\mathrm{pH}$ 7.2. This eluate was concentrated 100 times by positive-pressure filtration through an Amicon Diaflow membrane XM-100 (Amicon Corp., Lexington, Mass.).

In order to determine that the acid elution procedure was as effective on skin as it was on kidney tissue, the whole procedure was performed first on tissue sections. The elution procedure removed the IgG that was bound to the glomerular basement membrane easier than that bound to the skin basement membrane zone. In order to increase the yield of elution, several modifications were made in the procedure, and it was found that citrate buffer $\mathrm{pH} 2.2$ overnight at $37^{\circ} \mathrm{C}$ was a much more effective method to remove antibodies. This technique was used thereafter for all skin specimens. A series of experiments were performed using a serum antinuclear antibody of known titer, to see if the extreme acid $\mathrm{pH}$ might affect the antibody activity. A decrease of three dilutions (to $1: 512$ ) in the titer of the antibody was 
found when $\mathrm{pH} 2.2$ buffer was used, compared to a titer of $1: 4,096$ when $\mathrm{pH} 3.2$ buffer or normal saline was used. In spite of this, $\mathrm{pH} 2.2$ was preferred to $\mathrm{pH} 3.2$ because the lower $\mathrm{pH}$ increases the yield from elution several fold.

DNAse treatment. Cryostat sections of kidney and skin were placed in Coplin jars and exposed overnight at $4^{\circ} \mathrm{C}$ to $0.2 \mathrm{mg}$ of DNAse (Sigma Chemical Co., St. Louis, Mo.) and $0.003 \mathrm{M}$ magnesium chloride in $20 \mathrm{ml}$ of phosphate-buffered saline at $\mathrm{pH}$ 6.9. This technique failed to remove a significant amount of the basement membrane bound antibody compared with the acid clution technique and was therefore abandoned.

\section{Antibody characterization}

Column chromatography. Chromatographic separation of the serum from case 3 was performed to define and dissociate various antinuclear antibodies and to increase the possibility of detecting any other circulating antibody (such as antibasement membrane antibody) that might be masked in the whole serum. Diethylaminoethyl cellulose (Whatman DE-52) chromatography was carried out as described elsewhere (8). The presence of antinuclear antibody and of basement membrane antibody was examined in each peak with the use of monkey esophagus and fluorescein-tagged anti-IgG as described previously. In addition, IgG subclassing was performed with the use of conjugates prepared by Dr. P. H. Schur. The characteristics of these antibodies have been previously described (8).

Quantitative radial immunodiffusion plates. The IgG concentration on each serum or eluate was determined by radial immunodiffusion using commercially available immunoplates and appropriate standards.

Specificity studies. Antigens for specificity studies (native DNA, denatured DNA, phosphate-buffered saline nuclear extract, and nucleoprotein) were prepared exactly as described by Koffler et al. (7). In addition, a commercial preparation of nucleoprotein (thymus nucleoprotein HC1035/1, Hormon-Chemie, Munich, West Germany) was used at a concentration of $4 \mathrm{mg} / \mathrm{ml}$.

A modified Ouchterlony technique was used to detect the precipitin lines between antigen and antibody; $0.4 \%$ agarose in $0.01 \mathrm{M}$ phosphate-buffered saline at $\mathrm{pH} 7.2$ was poured into Petri dishes, and holes $8 \mathrm{~mm}$ in diameter were punched $4 \mathrm{~mm}$ apart.

Inhibition studies were performed by incubating serial dilutions of serum or eluate with an equal volume of antigen or saline for $60 \mathrm{~min}$ at $37^{\circ} \mathrm{C}$ or overnight at $4^{\circ} \mathrm{C}$. They were then centrifuged for $30 \mathrm{~min}$ at $10,000 \mathrm{~g}$, followed by indirect immunofluorescence of the supernatant for the detection of antinuclear antibodies.

Detection of hemagglutinating antibody to an extractable nuclear antigen (ENA) was performed by Dr. Gordon Sharp, using tanned sheep red blood cells coated with ENA $(9,10)$. Immunofluorescence studies of the serum or eluates were performed on tissue section that had been previously treated with RNAse or according to a previcusly described technique.

Preparation of fluorescein isothiocyanate (FITC)-labeled antibasement membrane antibodies. A patient with active bullous pemphigoid was plasmaphoresed. This plasma had a titer of $1: 2,560$ for basement membrane antibody. The plasma was chromatographed on DEAE cellulose as previously described for the SLE serum, and each fraction was concentrated and tested for the presence of basement membrane antibody, which was found in all four fractions. Complement fixing activity, however, was limited to fraction 1. All four fractions were then subclassed and found to contain IgG3 in fraction 1. Fraction 2 contained IgG1 and IgG4, fraction 3 contained IgG4, and fraction 4 contained IgG3. Whole pemphigoid serum as well as fractions 1 and 3 from the DEAE column was labeled.

Crystalline, desiccated fluorescein isothiocyanate (BBL, division of BioQuest, Cockeysville, Md.) was stored in the dark at $4^{\circ} \mathrm{C}$ until used. Conjugation was carried out following the method of Wood, Thompson, and Goldstein (11). Comparative studies of serial dilution showed a definite superiority of the labeled fractions 1 and 3 over the whole pemphigoid serum. Labeled fraction 1 was used in the remainder of the studies at a dilution $1: 200$.

This labeled basement membrane antibody was used to establish whether the antibody eluted from SLE skin shared a common antigenic determinant with pemphigoid antibody. Sections of guinea pig esophagus were overlayed with eluate from SLE or normal skin and were then stained with the fluorescein-labeled pemphigoid antibody.

Skin eluate from case 3 was also labeled with FITC as previously described. Sections of guinea pig esophagus were overlayed with serum of a patient with high titer of pemphigoid antibody and were then stained with the fluorescein-labeled skin eluate. In order to take into consideration both the specificity and the affinity of the two antibasement membrane antibodies, units (corresponding to the highest dilutions of labeled or unlabeled pemphigoid serum and skin eluate still staining the basement membrane) were used in serial comparisons.

In order to rule out the possibility that an eluted immune complex might bind nonspecifically at the basement membrane area, hemocyanin-antihemocyanin soluble and insoluble complexes were applied to guinea pig esophagus sections and then were counterstained with antihuman IgG conjugate. Hemocyanin antibody was obtained from a human volunteer immunized with hemocyanin antigen obtained from the horsecrab (Limulus polyphemus). The tissue was exposed to this complex for $30 \mathrm{~min}$.

\section{RESULTS}

\section{Tissue, serum, and eluate studies}

Tissue studies. Direct immunofluorescence was performed on each tissue obtained to determine the location of in vivo bound immunoglobulins and complement ( $\mathrm{Ta}$ ble III).

TABLE III

Direct Immunofluorescence of Tissues

\begin{tabular}{lllll}
\hline Case & \multicolumn{1}{c}{ Tissue } & Anti-IgG & Anti-IgM & \multicolumn{1}{c}{$\begin{array}{c}\text { Anti- } \\
\boldsymbol{\beta}_{1} \mathrm{C} / \boldsymbol{\beta}_{1} \mathrm{~A}\end{array}$} \\
\cline { 1 - 4 } 1 & Skin & BM*1/2+ & Neg. & Neg. \\
& Kidney & BM 2+ & $1+$ & $2+$ \\
& Trachea & BM 2+ & Neg. & Neg. \\
& Gut, esophagus & BM neg. & $1+$ & Neg. \\
2 & Skin & BM 2+ & $1+$ & Neg. \\
& Kidney & BM 1+ & $1+$ & $1+$ \\
3 & Skin & BM 1-2+ & Neg. & Not done \\
& Kidney & BM 1-2+ & Neg. & $1+$ \\
& Gut & BM neg. & $\cdots$ & Neg. \\
\hline
\end{tabular}

* Basement membrane. 

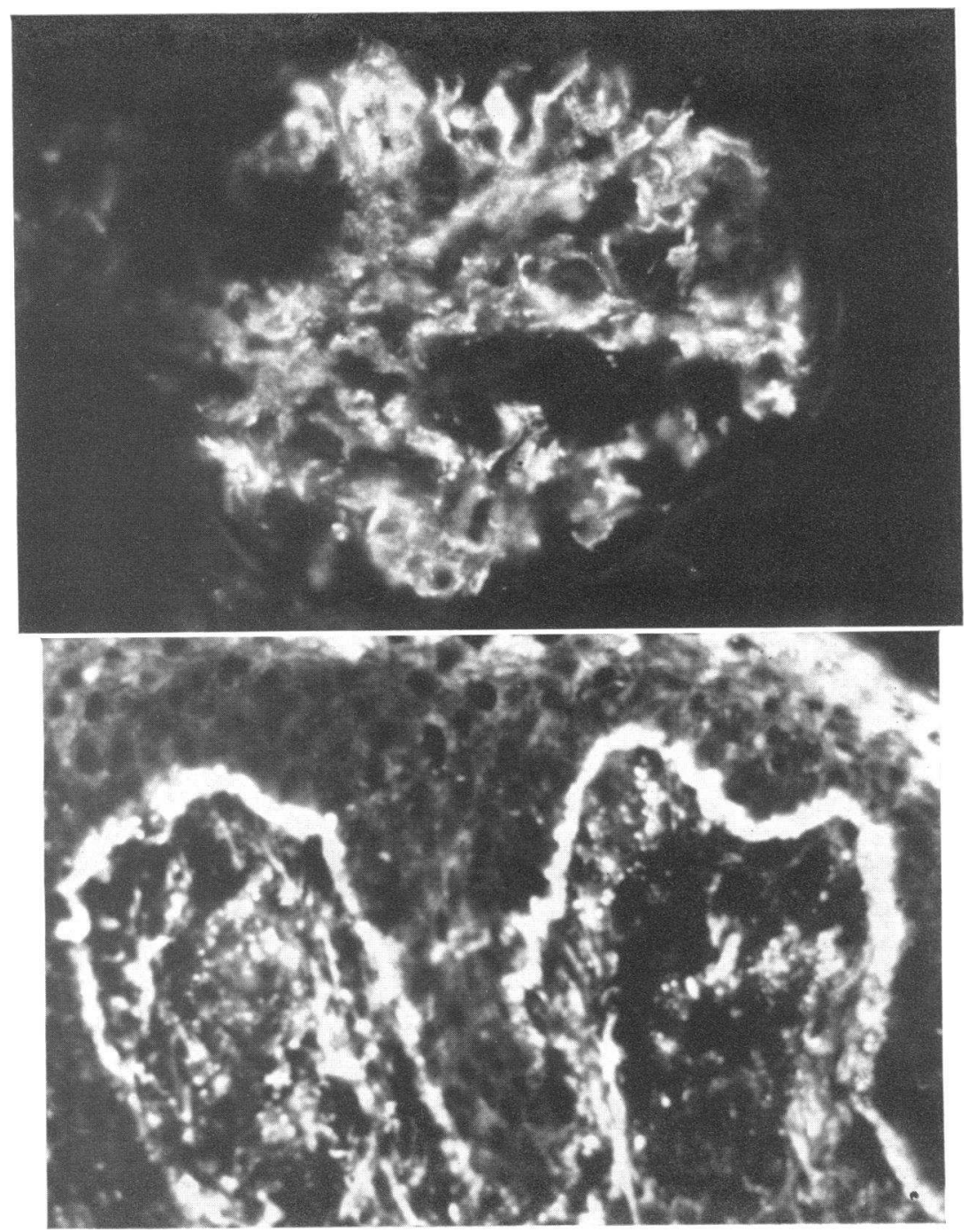

FIGURE 1 Case 1. Upper: Granular deposits of IgG along glomerular basement membrane. (Fluorescein-conjugated antihuman IgG; $\times 250$.) Lower: Granular deposits of IgG along basement membrane zone, separating epidermis from dermis. (Fluorescein-conjugated antihuman IgG; $\times 250$.)

Immunofluorescent studies on the tissues revealed granular IgG deposits in the glomerular basement membrane (Fig. 1, Upper) and in the skin basement membrane zone of all three patients with SLE (Fig. 1, Lower). In addition, complement was fixed to the glomerular basement membrane of all three patients but not to the skin basement membrane zone. Some other tissues also showed deposits of $\operatorname{IgG}$ or IgM at their basement membrane but not in a consistent manner. The pattern of fluorescence was always granular or finely stippled but never linear, such as found in bullous pemphigoid or glomerulonephritis. No antinuclear antibodies were fixed in vivo to the nuclei of the host tissues.
Serum studies. Indirect immunofluorescence was performed on the sera from all patients to determine the titer and pattern of immunofluorescence with various conjugates.

All the sera had mixed patterns, indicating the presence of several types of antinuclear antibodies. The homogeneous pattern disappeared as the sera were diluted, often leaving clear peripheral patterns. The antinuclear antibody in all patients fixed complement but at lower dilutions than that required to produce antinuclear antibody staining, indicating possibly that some of the antinuclear antibody in each serum did not fix complement. 


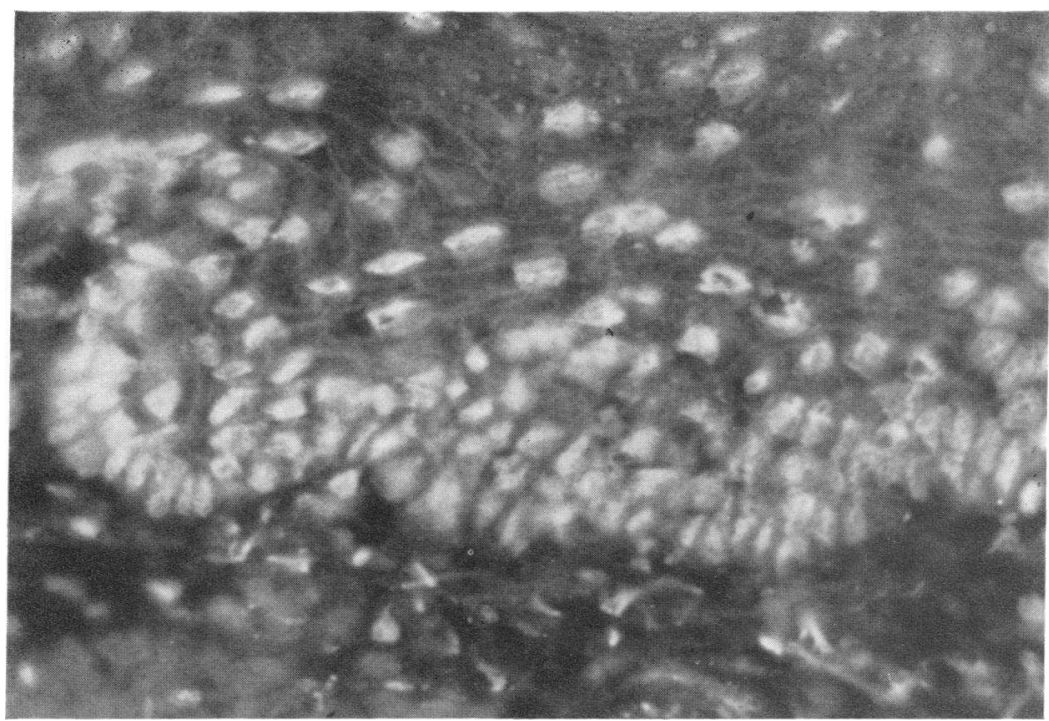

Figure 2 Case 1. Kidney eluate on guinea pig esophagus, showing strong antinuclear antibody but no antibasement membrane antibody. (Fluorescein-conjugated antihuman IgG; $\times 400$.)

All sera contained antinuclear antibody of $\operatorname{IgM}$ as well at of IgG types.

Eluate studies. The kidney eluate from all three patients showed strong antinuclear antibody in all tissues (Fig. 2) but no evidence of a basement membrane antibody for either glomerular or epithelial tissue (Table IV). All three skin eluates possessed antinuclear antibody, but two of the three had a strong antibody for the basement membrane of epithelial tissue (Fig. 3, Upper and Lower). Eluates from normal breast skin did not contain any demonstrable antibody.

\section{Characterization of antinuclear antibody in} eluates

Affinity for different antigens. Some eluates stained only the nuclei of fibroblasts. In eluates with high titer of antinuclear antibody, both epidermal and fibroblast nuclei fluoresced.

Immunofluorescent pattern of antinuclear antibody. In kidney eluates, the dominant pattern was peripheral and in case 3 a speckled, thready pattern also was predominant through the nuclei. This pattern is characteristic for antibodies to extractable nuclear antigen (ENA), which was found in case 3. However, this particular antibody to ENA is most likely the type to be associated with SLE rather than with mixed connective tissue diseases (10) because the antibody titer was low and because the eluate still reacted to produce the speckled pattern of antinuclear fluorescence after treatment of tissue sections with RNAse. The skin eluates produced a mixed pattern, sometimes with peripheral accentuation, but the latter was never as predominant as with the kidney eluates.

Titer of antinuclear antibody. The titer of antinuclear antibody was high in all kidney eluates and, in case 3, appeared to be three dilutions higher than that observed in the serum (Table V). (Only in case 3 was the whole kidney available for elution.) This means that the titer of antinuclear antibody was proportional to the amount of tissue available, since all eluates were concentrated to the same final volume. More meaningful is the comparison of the minimal IgG concentration of serum and eluate that gave antinuclear antibody reaction.

Quantitation of the total IgG represented as antinuclear antibody. When the $\gamma$-globulin concentrations of the serum and eluate were compared in the same patient, in all three cases the amount of antibody relative to total IgG was much greater in the eluates than

TABLE IV

Eluate Antibodies

\begin{tabular}{llcc}
\hline \multirow{2}{*}{ Antibody } & & \multicolumn{2}{c}{ Eluate } \\
\cline { 3 - 4 } Antinuclear & Substrate & Kidney & Skin \\
\cline { 3 - 4 } $\begin{array}{l}\text { Liver } \\
\text { Gainea pig } \\
\text { esophagus } \\
\text { membrane }\end{array}$ & Pos. 3/3 & Pos. 3/3 \\
& Human kidney & Neg. 3/3 $3 / 3$ & Pos. 3/3 \\
& Guinea pig & & \\
& esophagus & Neg. 3/3 & Pos. 2/3 \\
& Human skin & Neg. 3/3 & Pos. 2/3 \\
\hline
\end{tabular}




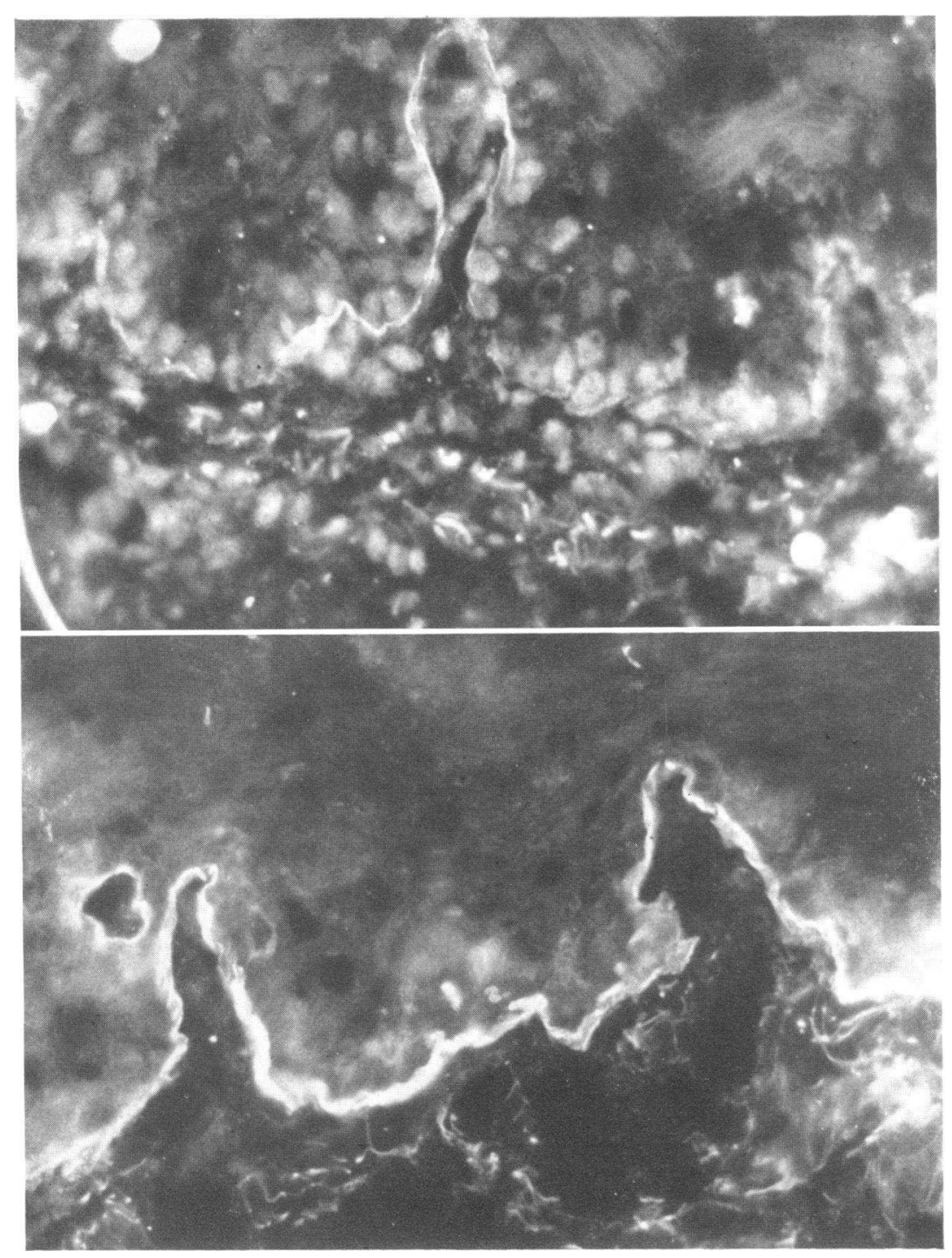

FIgURE 3 Case 3. Skin eluate. Upper: On guinea pig esophagus, showing both antinuclear and antibasement membrane zone antibodies. (Fluorescein-conjugated antihuman IgG; $\times 400$.) Lower: On rabbit esophagus, showing very strong antibasement membrane zone antibody, which displays a tubular, folded appearance. Although this tissue gave a better demonstration of antibasement membrane zone antibody than did guinea pig esophagus, it did not demonstrate antinuclear antibody. (Fluorescein-conjugated antihuman IgG; $\times 400$.)

TABLE V

Titers of Antinuclear Antibody (ANA) and Antibasement Membrane Antibody $(B M-A b)$

\begin{tabular}{|c|c|c|c|c|}
\hline \multirow[b]{2}{*}{ Case } & \multirow{2}{*}{$\begin{array}{l}\text { Serum } \\
\text { ANA }\end{array}$} & \multirow{2}{*}{$\begin{array}{l}\text { Kidney } \\
\text { eluate } \\
\text { ANA }\end{array}$} & \multicolumn{2}{|c|}{ Skin eluate } \\
\hline & & & $A N A$ & $\mathrm{BM}-\mathrm{Ab}$ \\
\hline 1 & $1: 256$ & $1: 128$ & $1: 8$ & Neg. \\
\hline 2 & $1: 256$ & $1: 64$ & $1: 1$ & $1: 4$ \\
\hline 3 & $1: 64$ & $1: 512$ & $1: 8$ & $1: 32$ \\
\hline
\end{tabular}

M. Landry and W. M. Sams, Jr. in the serum (Table VI). The ratio of the minimal serum to eluate $\gamma$-globulin that gave antinuclear antibody staining varied from 3 to 200 . It was lower in antinuclear antibody from skin eluates, partly because small amounts of $\mathrm{IgG}$ were extracted from the skin and partly because the IgG eluted from the skin was predominantly antibasement membrane zone antibody. The minimal $\gamma$-globulin concentration that gave antinuclear antibody staining had to be calculated since, at such dilution, neither serum nor eluate gave precipitin 
TABLE VI

Iinimal Concentrations of Serum and Eluate IgG Giving .Intinuclear (.1N.1) and Antibasemenl Mcmbrane $(B M)$ Fluorescence Reactions

\begin{tabular}{|c|c|c|c|c|c|c|}
\hline \multirow[b]{2}{*}{ Case } & \multirow[b]{2}{*}{ Serum } & \multirow{2}{*}{$\begin{array}{l}\text { Kidney } \\
\text { eluate }\end{array}$} & \multirow{2}{*}{$\begin{array}{c}\text { Ratio } \\
\text { of } \\
\text { serum } \\
\text { IgG/ } \\
\text { eluate } \\
\text { IgG }\end{array}$} & \multicolumn{2}{|c|}{ Skin eluate } & \multirow{2}{*}{$\begin{array}{c}\begin{array}{c}\text { Ratio } \\
\text { of } \\
\text { serum } \\
\text { IgG/ } \\
\text { eluate } \\
\text { IgG }\end{array} \\
\text { ANA }\end{array}$} \\
\hline & & & & ANA & $\mathrm{BM}$ & \\
\hline & $\mu g I g G / m l$ & $\mu g I g G / m l$ & \multicolumn{4}{|c|}{$\mu g I g G / m l$} \\
\hline 1 & 0.140 & 0.0025 & 56 & 0.045 & $\ldots$ & 3 \\
\hline 2 & 0.260 & 0.0022 & 118 & 0.02 & 0.005 & 13 \\
\hline 3 & 0.100 & 0.0006 & 166 & 0.009 & 0.002 & 11 \\
\hline
\end{tabular}

lines in the immunoplates. Those values were extrapolated from a curve constructed from known IgG values of serum and eluate at lesser dilutions.

Antinuclear antibody IgG subclasses. Determination of IgG subclass using monospecific fluoresceinconjugated antihuman subclasses revealed $\operatorname{IgG} 3$ in all sera and eluates, and IgG2 in all except the kidney eluate of case 2. IgG1 was found in two sera but not in eluates (Table VII).

Antinuclear Antibody IgM. All three sera contained an IgM antibody of high titer. However, only trace amounts and often no IgM were found in the eluates.

Column Chromatography. DEAE cellulose chromatography of serum from case 3 demonstrated no antinuclear antibody in the first three peaks-these contained the bulk of the IgG-but high titer of antibody was found in the fourth or last peak. Subclassing revealed that this was IgG3 only. No IgG2 was detectable in any peak, even though this patient's whole serum did give evidence of IgG2 (Fig. 4). This antibody activity also could be limited to the last eluted fraction because it is in the formation of an immune complex, hut this possibility was not studied.

TABLE VII

Antinuclear Antibody: Complement-Fixing Ability and IgG Subtypes

\begin{tabular}{|c|c|c|c|c|c|c|}
\hline Case & Source & $\beta_{1} \mathrm{C} / \beta_{1} \mathrm{~A}$ & $\operatorname{IgG1}$ & IgG2 & $\mathrm{IgG} 3$ & IgG4 \\
\hline \multirow[t]{3}{*}{1} & Serum & + & + & + & + & $\mathrm{ND}^{*}$ \\
\hline & Kidney eluate & + & Neg. & Neg. & + & NI) \\
\hline & Skin eluate & + & ND & ND & ND & ND \\
\hline \multirow[t]{3}{*}{2} & Serum & + & + & + & + & NI) \\
\hline & Kidney eluate & + & Neg. & + & + & $\mathrm{ND}$ \\
\hline & Skin eluate & ND & ND & ND & ND & N゙D \\
\hline \multirow[t]{3}{*}{3} & Serum & + & Neg. & + & + & Neg. \\
\hline & Kidney eluate & + & Neg. & + & + & Neg. \\
\hline & Skin eluate & + & Neg. & + & + & Neg. \\
\hline
\end{tabular}

* ND, not done.

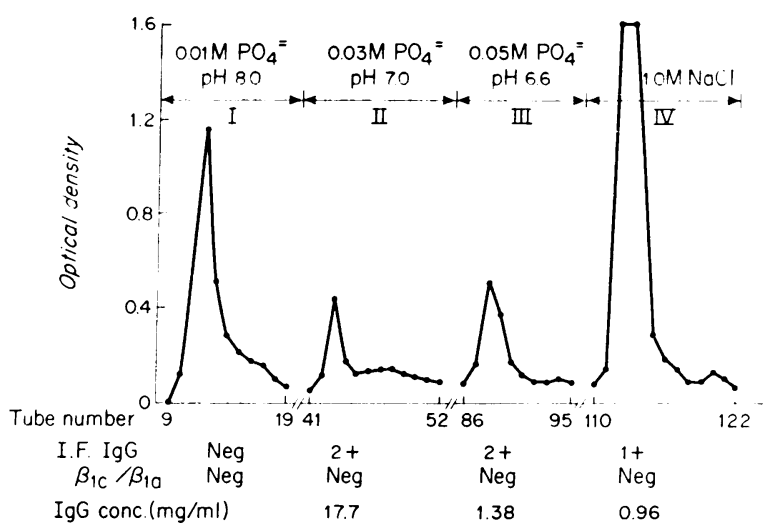

Figure 4 Case 3. DEAE-cellulose chromatography of serum. Antinuclear antibody was found in all peaks except the first.

Complement-fixing characteristics of the antinuclcar antibody. All three kidney-eluted antinuclear antibodies and two skin-eluted antinuclear antibodies could be demonstrated to fix complement (Table VII). Insufficient skin eluate was available from case 2 for complement-fixing studies.

Specificity studies. Immunoprecipitation tests required large amounts of serum and did not detect any antibody, which was revealed by more sensitive methods such as immunofluorescence and hemagglutination. $\mathrm{Ab}$ sorption was attempted with all sera and with some eluates, but only partial inhibition of fluorescence was seen with phosphate-buffered saline nuclear extract and with no other antigens tested. Hemagglutination detected deoxyribonucleic acid antibody both in serum and kidney eluate of one patient and extractable nuclear antibody both in the serum and kidney eluate of the third case (Table VIII). However, antibodies other than those to deoxyribonucleic acid or nuclear extract must have been present in case 1 kidney eluate and in all three skin eluates to explain the presence of positive antinuclear antibody staining.

TABLE VIII

Specificity Studies Using Hemagglutination Method

\begin{tabular}{cllll}
\hline & & & \multicolumn{2}{c}{ Eluate } \\
\cline { 5 - 5 } Case & Antibody* & Serum & Kidney & Skin \\
\hline 1 & ENA-Ab & Neg. & Neg. & Neg. \\
& DNA-Ab & $+1: 320$ & Neg. & Neg. \\
2 & ENA-Ab & Neg. & Neg. & Neg. \\
& DNA-Ab & $+1: 10$ & $+1: 40$ & Neg. \\
3 & ENA-Ab & $+1: 320$ & $+1: 640$ & Neg. \\
& DNA-Ab & Neg. & Neg. & Neg. \\
\hline
\end{tabular}

* ENA, extractable nuclear antibody; DNA, deoxyribonucleic acid antibody. 
Characterization of basement membrane antibody in eluates

Affinity for differenl antigens. All eluates were tested on basement membranes of epithelial (guinea pig esophagus and human skin) and human kidney tissues. The eluted antibody reacted with guinea pig esophagus and human skin basement membrane, but not with glomerular basement membrane. This is also characteristic of the antibody found in patients with pemphigoid, a bullous disease of the skin.

Pattern of basement membrane antibody. The immunofluorescent pattern of eluted basement membrane antibody differed from the antibody fixed to the basement membrane in vivo and observed by direct immunofluorescence. On direct immunofluorescent examination of the skin, the antibody presented a granular lumpy-bumpy appearance in the basement membrane area (Fig. 1, Lower). However, eluted basement membrane antibody showed a linear and tubular staining of the basement membrane similar to that observed in bullous pemphigoid (Fig. 3).

Titer of basement membrane antibody. The titer of antibasement membrane antibody in the skin eluates was $1: 32$ in case 3 and $1: 4$ in case 2 . No circulating basement membrane antibody was detectable in the corresponding serum. The skin eluates had a much higher titer of antibasement membrane antibody $(1: 32)$ than of antinuclear antibody $(1: 8)$.

Basement membrane antibody IgG subclasses. All eluted basement membrane antibodies were of the IgG

TABLE IX

Specificity Studies of the SLE Skin-Eluted Basement Membrane Antibody

\begin{tabular}{|c|c|c|c|c|}
\hline \multicolumn{2}{|c|}{ Skin eluate } & \multicolumn{2}{|c|}{ Pemphigoid conjugate } & \multirow[b]{2}{*}{ Result } \\
\hline Dil. & Units & Dil. & Units & \\
\hline $1: 1$ & 5 & $1: 32$ & 4 & - \\
\hline $1: 2$ & 4 & $1: 32$ & 4 & - \\
\hline $1: 4$ & 3 & $1: 32$ & 4 & $1+$ \\
\hline $1: 8$ & 2 & $1: 32$ & 4 & $1+$ \\
\hline $1: 16$ & 1 & $1: 32$ & 4 & $2+$ \\
\hline \multicolumn{2}{|c|}{ Pemphigoid serum } & \multicolumn{2}{|c|}{ Skin eluate conjugate } & Result \\
\hline $1: 1$ & 10 & $1: 8$ & 2 & - \\
\hline $1: 2$ & 9 & $1: 8$ & 2 & 一 \\
\hline $1: 4$ & 8 & $1: 8$ & 2 & $(+)$ \\
\hline $1: 8$ & 7 & $1: 8$ & 2 & $1+$ \\
\hline $1: 16$ & 6 & $1: 8$ & 2 & $1+$ \\
\hline $1: 32$ & 5 & $1: 8$ & 2 & $2+$ \\
\hline $1: 64$ & 4 & $1: 8$ & 2 & $2+$ \\
\hline $1: 128$ & 3 & $1: 8$ & 2 & $2+$ \\
\hline $1: 256$ & 2 & $1: 8$ & 2 & $2+$ \\
\hline $1: 512$ & 1 & $1: 8$ & 2 & $2+$ \\
\hline
\end{tabular}

type, but attempts to determine the subclass of IgG failed, presumably because of the relative weakness of the subclass conjugates used.

Column chromatography (Case 3). No circulating basement membrane antibody was demonstrable in any of the four peaks.

Basement membrane antibody complement-fixing ability. The eluted basement membrane antibody from case 3 was capable of fixing complement. Insufficient eluate was available for complement-fixation studies in the other case.

Specificity studies. Two types of experiments were performed. The skin eluates were first absorbed with a powder prepared by finely pulverized esophagus of the cow, but no reduction in basement membrane staining was detectable when compared with control eluates. When the eluates were absorbed with 50-100 4- $\mu \mathrm{m}$ cryostat sections of guinea pig esophagus, only a weak reduction of staining was noted in the eluates. We tried a second approach. Since the eluted basement membrane antibody had the same affinity for tissue antigen and gave the same pattern as pemphigoid antibody, we attempted to block the basement membrane staining of a fluorescein-tagged pemphigoid antibody from fraction 1 by prior incubation with the skin eluate. This resulted in marked reduction of the basement membrane staining.

Further studies were pursued to determine if this proves the identity of the antibody binding sites or just reflects a quantitative difference in the two antibodies. To take into consideration the relative concentration of antibody present both in serum and in conjugate, a system of units was adopted, one unit corresponding to the highest dilution still giving basement membrane staining (Table IX). Serial units of serum were tested against serial units of conjugate to determine the mutual value necessary for blocking, each unit being successively added to the tissue section. 4 units of eluate were needed to block 4 units of conjugated pemphigoid serum, but 9 units of pemphigoid serum were required to block 2 units of conjugated skin eluate. These results point to a different affinity, if not specificity, of the two basement membrane antibodies for the basement membrane antigenic sites.

In addition, when these units of pemphigoid serum and conjugated eluate were first mixed together and then applied to the tissue section, no blocking was observed. This result again points out the different affinity or specificity (or both), since the two antibodies have an equal opportunity to bind to the basement membrane, and the failure to block under these circumstances assumes that there are different binding sites. The blocking observed in the prior experiment may be due to the relatively enormous amount of pemphigoid 
antibody that occupies most of the basement membrane area rather than a specific site.

The application of hemocyanin-antihemocyanin complexes to guinea pig esophagus did not fix to the basement membrane zone, ruling out the possibility that an eluted immune complex might bind nonspecifically at the basement membrane area.

\section{DISCUSSION}

Current evidence indicates that lupus nephritis results from deposition of inmune complexes on the renal glomeruli (12). Koffler et al. (7) used acid elution and deoxyribonuclease to dissociate the antibody from this complex on kidneys of diseased patients and found that the antibody reacted to nuclei but not to basement membrane. Similar results were obtained by Krishnan and Kaplan (13) using acid elution alone. In addition to renal glomeruli, patients with SLE have complexes that are bound to other structures such as splenic vessels, from which an antinuclear antibody may be eluted (14).

The present study was undertaken to determine whether the antibodies demonstrable by direct immunofluorescence in the skin of patients with SLE are similar to those found in other structures. The skin of three patients was studied, all of which showed antibody bound in vivo to the basement membrane zone, but not to the nuclei. Acid elution of this skin revealed, as expected, an antinuclear antibody from the clinically normal skin of all three patients. An unexpected finding, however, was elution of an antibasement membrane antibody from two of the three patients (15).

As our studies progressed, we became aware of a preliminary report by Beyvin and Thivolet (16) which has since been published in full (17). They performed acid elution at $\mathrm{pH} 3.2$ on $254-\mu \mathrm{m}$ sections of biopsy specimens from five patients with SLE. In one of the cases they obtained the same result as we did, namely, that antibodies to nuclei and to epithelial basement membranes were eluted.

The basement membrane antibody that we eluted gave a fine linear pattern when reacted with epithelial tissue. This linear pattern is not obviously present when tissues are examined by direct immunofluorescence, an observation that we believe indicates a simple masking by the strong lumpy-bumpy pattern of the hound complexes. However, Burnham and Fine (18) have published a photograph of what may be both patterns in the same tissue. An attempt was made in our preparations to determine if these two patterns could be discerned. Cryostat-tissue sections of SLE skin were extracted on microscope slides in 0.2 incremental $\mathrm{pH}$ units from $\mathrm{pH} 3.2$ to 2.2 to determine if the antinuclear antibody might he removed and leave the basement membrane antibody. But no distinction could be found: all fixed antibody was removed as $\mathrm{pH} 2.2$ was approached.

The eluted antibody gave the same immunofluorescent pattern as did the pemphigoid antibody. Pemphigoid is a bullous cutaneous disease in which $\mathrm{TgG}$ antibodies are fixed to the skin in vivo as well as circulating in the serum, and, as in Goodpasture's syndrome, involves antibody interaction with antigen at a specific site rather than an immune complex. Thus, we wondered whether pemphigoid antibody and the eluted basement membrane zone antibody shared a common antigenic site.

The blocking experiment did not confirm this impression. On the contrary, it seems that the two antibodies occupy different sites on the basement membrane because very high titered pemphigoid serum is required to block very diluted skin eluate conjugate and because the simultaneous addition of the two antibodies suppresses the blocking. It is conceivable that antigenic sites of different sizes or spatial arrangement existed. In such a situation. blocking of any magnitude occurs because the first occupant in the area prevents the second from attaching. This does not mean that the two antibodies compete for the same antigenic site. Perhaps steric hindrance prevented a second antibody from reacting with its homologous determinant situated at a site close to another antigenic determinant.

Nonetheless, the two basement membrane antibodies remain close to each other, because they both involve a specific interrelation with basement membrane antigen. It explains why the same immunofluorescent tubular pattern is found in both cases. As mentioned previously, the tubular versus the granular pattern is not diagnostic per se but reflects the immunopathologic mechanism of separate antigen-antibody interrelationship versus immune complex disease. In SLE, it seems that we are dealing with both an immune complex and a separate antigen-antibody interaction.

The presence of antinuclear antibody in the skin indicates that the same process of immune complex may be occurring in that site as occurs in the kidney. As Koffler et al. (7) demonstrated, there is a concentration of antinuclear antibody in glomeruli; we found a similar concentration in the skin (Table VI), indicating the same process in both organs. Just as the antinuclear antibody complex, because of its large size, is deposited on the glomerular basement membrane, this complex perfuses into the skin and is deposited on the skin basement membrane area.

\section{ACKNOWLEDGMENTS}

This investigation was supported in part by Research Grant AM-5299 from the National Institutes of Health. U. S. Public Health Service. 


\section{REFERENCES}

1. Tuffanelli, D. L., D. Kay, and K. Fukuyama. 1969. Dermal-epidermal junction in lupus erythematosus. Arch. Dcrmatol. 99: 652.

2. Burnham, T. K., and G. Fine. 1971. The immunofluorescent "band" test for lupus erythematosus. III. Employing clinically normal skin. Arch. Dermatol. 103: 24.

3. Sams, W. M., Jr., and R. E. Jordon. 1971. Pemphigus antibodies: their role in disease. J. Invest. Dermatol. $56: 474$.

4. Chorzelski, T., S. Jabłońska, and M. Blaszczyk. 1968 Autoantibodies in pemphigoid. Dermatologica. 136:325.

5. Beutner, E. H., R. E. Jordon, and T. P. Chorzelski. 1968. The immunopathology of pemphigus and bullous pemphigoid. J. Invest. Dermatol. 51: 63.

6. Jordon, R. E., W. M. Sams, Jr., and E. H. Beutner. 1969. Complement immunofluorescent staining in bullous pemphigoid. J. Lab. Clin. Med. 74: 548 .

7. Koffler, D., P. H. Schur, and H. G. Kunkel. 1967. Immunological studies concerning the nephritis of systemic lupus erythematosus. J. Exp. Med. 126: 607.

8. Sams, W. M., Jr., and P. H. Schur. 1973. Studies of the antibodies in pemphigoid and pemphigus. J. Lab. Clin. Med. In press.

9. Sharp, G. C., W. S. Irvin, R. L. LaRoque, C. Velez, V. Daly, A. D. Kaiser, and H. R. Holman. 1971. Association of autoantibodies to different nuclear antigens with clinical patterns of rheumatic disease and responsiveness to therapy. J. Clin. Invest. 50:350.

10. Sharp, G. C., W. S. Irvin, E. M. Tan, R. G. Gould, and H. R. Holman. 1972. Mixed connective tissue disease: an apparently distinct rheumatic disease syndrome asso- ciated with a specific antibody to an extractable nuclear antigen (ENA). Am. J. Med. 52: 148.

11. Wood, B. T., S. H. Thompson, and G. Goldstein. 1965 Fluorescent antibody staining. III. Preparation of fluorescein-isothiocyanate-labeled antibodies. J. Immunol.95: 225.

12. Koffler, D., V. Agnello, R. Thoburn, and H. G. Kunkel. 1971. Systemic lupus erythematosus: prototype of immune complex nephritis in man. J. Exp. Med. 134:169s.

13. Krishnan, C., and M. H. Kaplan. 1967. Immunopathologic studies of systemic lupus erythematosus. II. Antinuclear reaction of $\gamma$-globulin eluted from homogenates and isolated glomeruli of kidneys from patients with lupus nephritis. J. Clin. Invest. 46:569.

14. Svec, K. H., and S. T. Allen. 1970. Antibody to nuclear material eluted from isolated spleen vessels in systemic lupus erythematosus. Science (Wash. D. C.). 170: 550.

15. Landry, M., and W. M. Sams, Jr. 1972. Basementmembrane antibodies in two patients with systemic lupus erythematosus. Lancet. 1: 821 .

16. Beyvin, A. J., and J. Thivolet. 1971. Les globulines fixées à la jonction dermo-épidermique dans le lupus érythémateux sont-elles des anticorps anti-membrane basale? Presse Med. 79 : 1070

17. Thivolet, J., A. J. Beyvin, and J. Le Mot. 1972. Elution des anticorps fixes in vivo au niveau de la peau au cours du pemphigus, de la pemphigoide bulleuse et du lupus erythemateux. Lyon Med. 227: 241.

18. Burnham, T. K., and G. Fine. 1969. The immunofluorescent "band" test for lupus erythematosus. I. Morphologic variations of the band of localized immunoglobulins at the dermal-epidermal junction in lupus erythematosus. Arch. Dermatol. 99 : 413. 